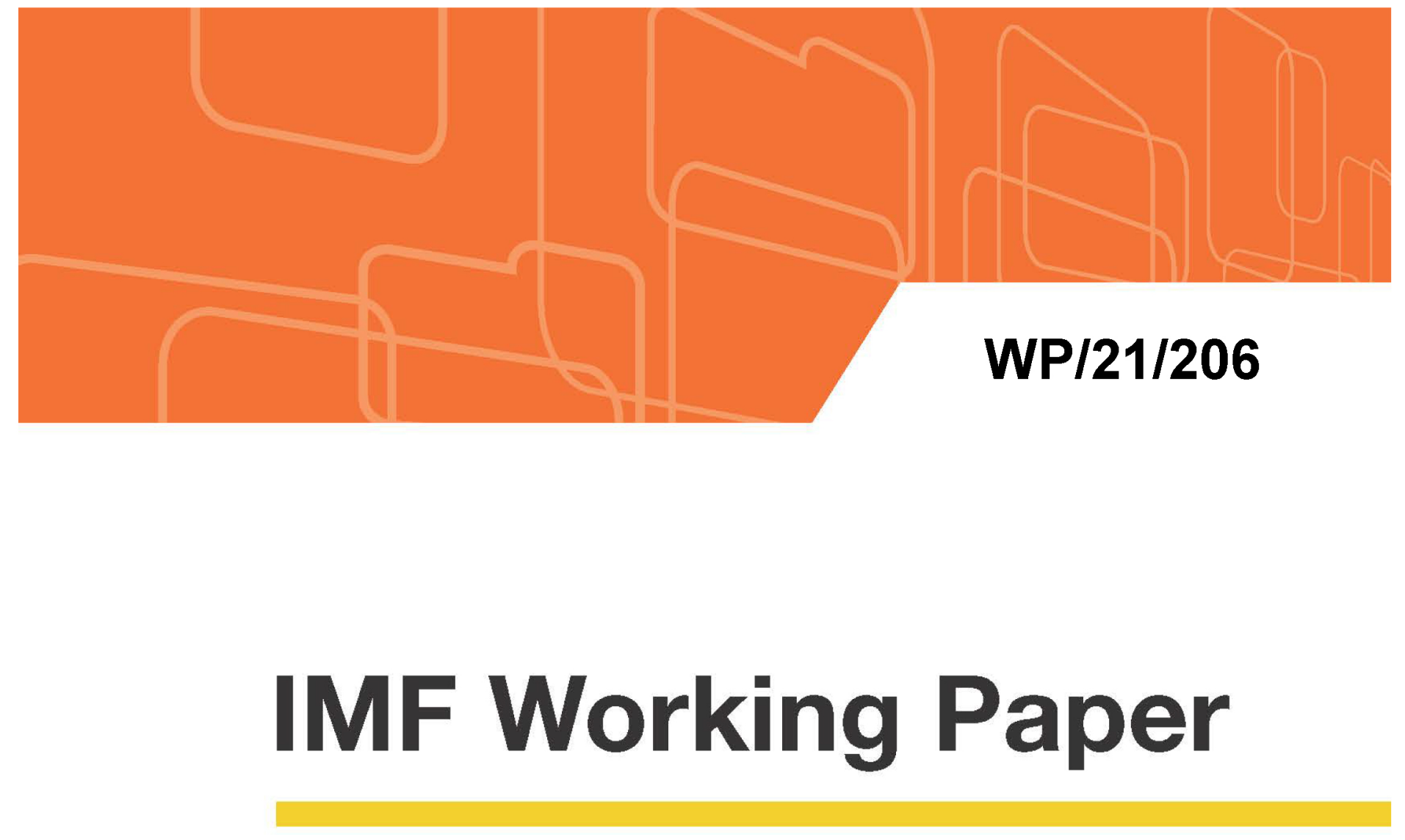

\title{
Real Estate in the Netherlands: A Taxonomy of Risks and Policy Challenges
}

by André Geis and Oana Luca

IMF Working Papers describe research in progress by the author(s) and are published to elicit comments and to encourage debate. The views expressed in IMF Working Papers are those of the author(s) and do not necessarily represent the views of the IMF, its Executive Board, or IMF management. 


\title{
IMF Working Paper
}

\author{
European Department
}

\section{Real Estate in the Netherlands: A Taxonomy of Risks and Policy Challenges Prepared by André Geis and Oana Luca ${ }^{1}$}

Authorized for distribution by Alfredo Cuevas

August 2021

\section{IMF Working Papers describe research in progress by the author(s) and are published to elicit comments and to encourage debate. The views expressed in IMF Working Papers are those of the author(s) and do not necessarily represent the views of the IMF, its Executive Board, or IMF management.}

\begin{abstract}
Soaring real estate prices and valuations despite the economic downturn brought by the pandemic have focussed the attention of Dutch policymakers on potential macro-financial and socio-economic implications. In this context, our paper reviews the salient features of Dutch commercial and residential real estate markets with an eye to identify pertinent risks and challenges. While we find that the Dutch authorities have made considerable strides to strengthen real estate-related policies in recent years, some, and partly longstanding, issues remain, requiring additional efforts to bolster financial stability, address housing supply shortages and manage secular changes affecting property markets.
\end{abstract}

JEL Classification Numbers: G21, G23, G28, R31, R33, R38

Keywords: residential real estate, commercial real estate, real estate market policies, housing policies, financial sector risks, financial sector policies, macroprudential policies

Author's E-Mail Address: AGeis@imf.org, OLuca@imf.org

\footnotetext{
${ }^{1}$ The analysis benefitted from helpful comments and suggestions by the authorities, Alfredo Cuevas and Mark Horton as well as from excellent research assistance by Yushu Chen.
} 


\section{A. Introduction}

With prices continuing to soar despite the economic dislocations brought by the pandemic, Dutch real estate has drawn renewed attention by policymakers. The trend towards higher house prices, in place since early 2014, has barely been interrupted by the recent crisis. Demand has been fueled by historically low mortgage interest rates while structural features of residential real estate (RRE) markets in the Netherlands, such as favorable tax treatment of owner-occupied housing and longstanding supply bottlenecks have further contributed to price pressures. ${ }^{2}$ Likewise, commercial real estate (CRE) prices have sustained their ascent, notwithstanding a turn in the investment cycle and a pick-up in vacancy rates. Moreover, the economic downturn has tended to reinforce structural shifts in multiple CRE segments, thereby adding to the challenge of interpreting market developments.

\section{Real Estate Market Developments in the Netherlands}

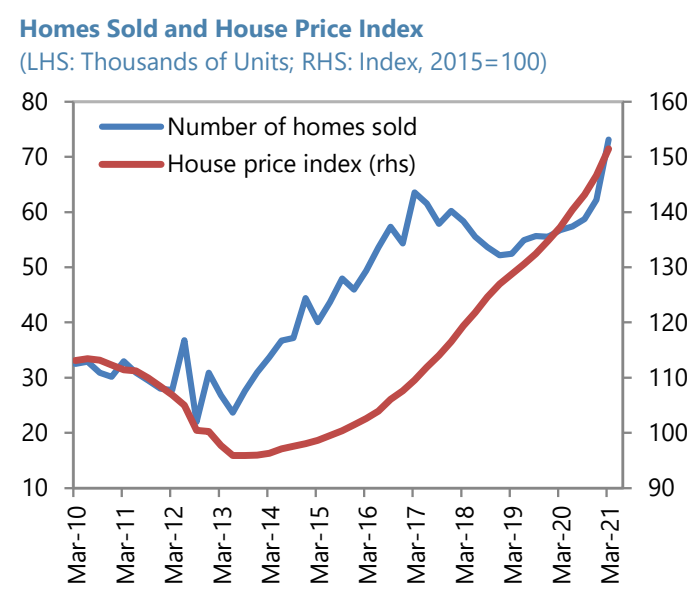

Sources: DNB.

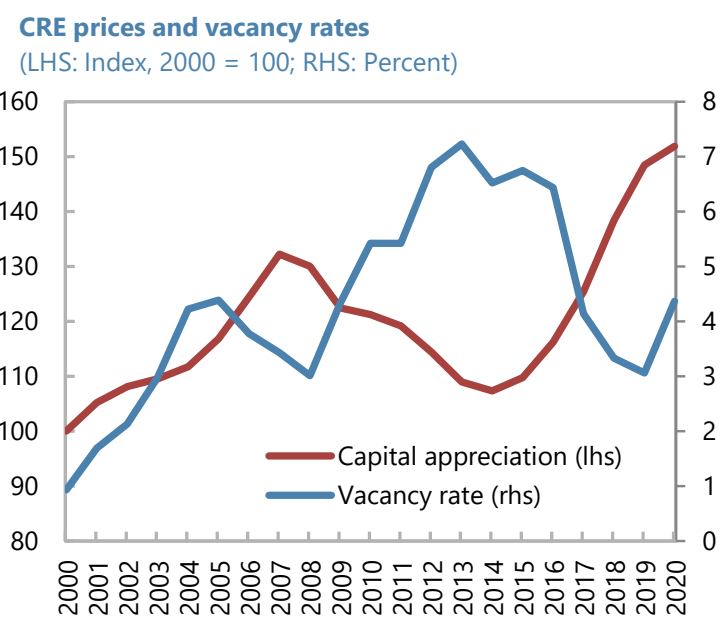

Sources: $\mathrm{MSCl}$

Elevated real estate prices have raised valuation concerns, particularly in light of the sizeable RRE and CRE portfolios maintained by the Dutch financial sector. Valuations of housing have risen substantially since 2014, with the increase in prices in relation to rents outpacing the euro area average. At the same time, mortgage debt by households, at more than 80 percent of GDP, has remained among the highest in the euro area, thereby exacerbating vulnerabilities. Similarly, financial institutions in the Netherlands rank among the most exposed to CRE risk in the euro area. While returns achievable by investing in CRE have fallen in recent years, they have remained attractive in comparison to safer alternatives,

${ }^{2}$ Johansson and Sánchez (2011) find that the long-run price elasticity of new housing supply in the Netherlands ranks among the lowest across a sample of OECD economies, potentially reflecting scarcity of land and tight land-use regulations. 
such as long-term government debt. ${ }^{3}$ Still, a sustained rise in bond yields may call valuations into question, potentially imposing losses on assets underpinned by CRE.

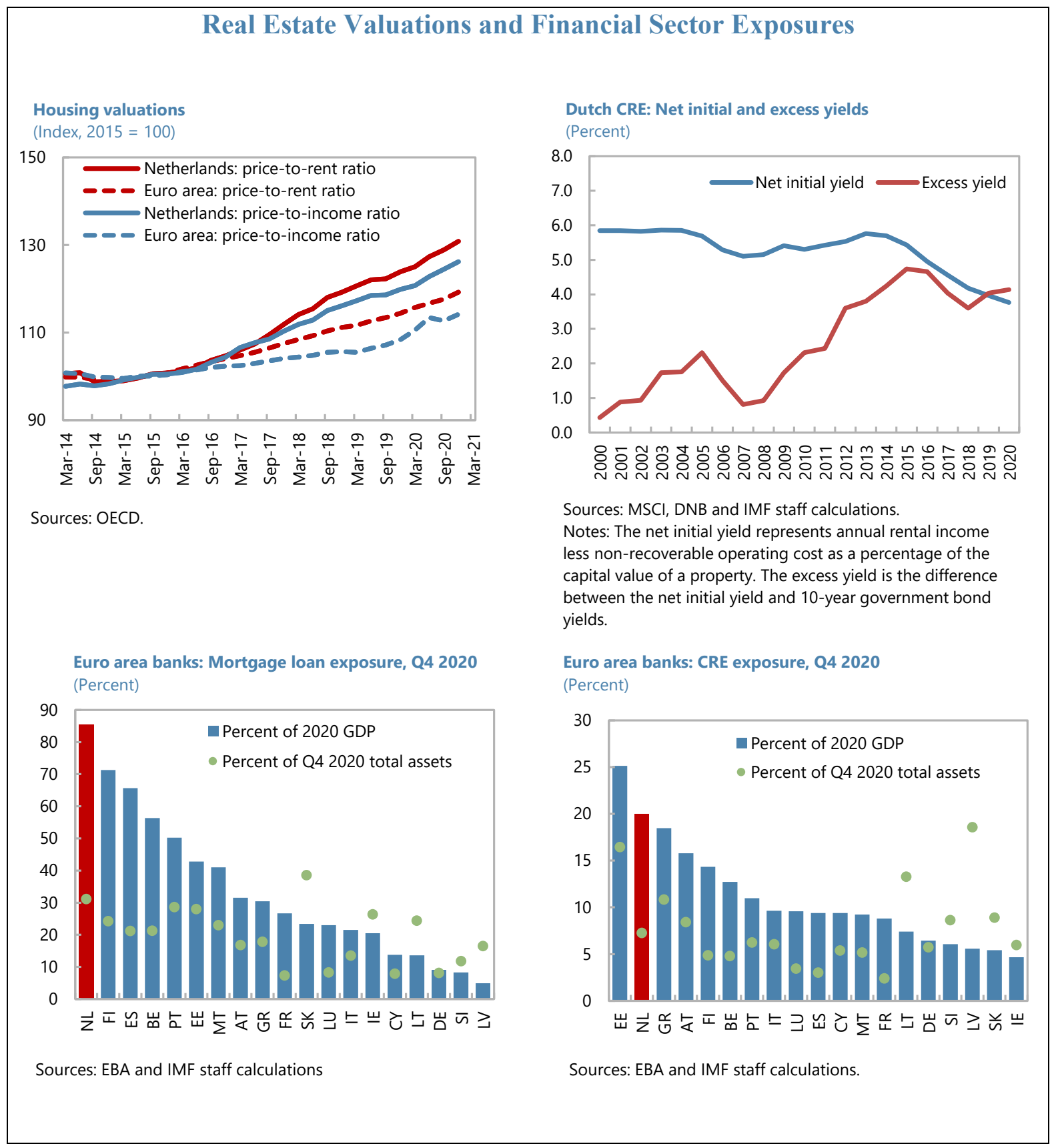

\footnotetext{
${ }^{3}$ In addition, income from CRE generally offers a rather stable source of income over the business cycle, making it an appealing asset for investors with a long-term horizon, such as insurance companies and pension funds.
} 
Expensive housing has also borne on social inequalities. The affordability of housing in the Netherlands, when measured as the relation of purchase prices to household incomes, has been on the wane since 2014, and more so than in the euro area. ${ }^{4}$ In turn, more expensive owner-occupied dwellings have been paralleled by rising prices for rental accommodation and, as a corollary, rents over 2014-20. While most low-income tenants have access to the large - and rent-controlled - social housing stock, groups of the population ineligible for such benefits and unwilling or unable to buy a property are confronted with a market characterized by a scarcity of affordable rentals. As a consequence, the cost of housing is making a sizeable contribution to inequality when compared to other European countries.

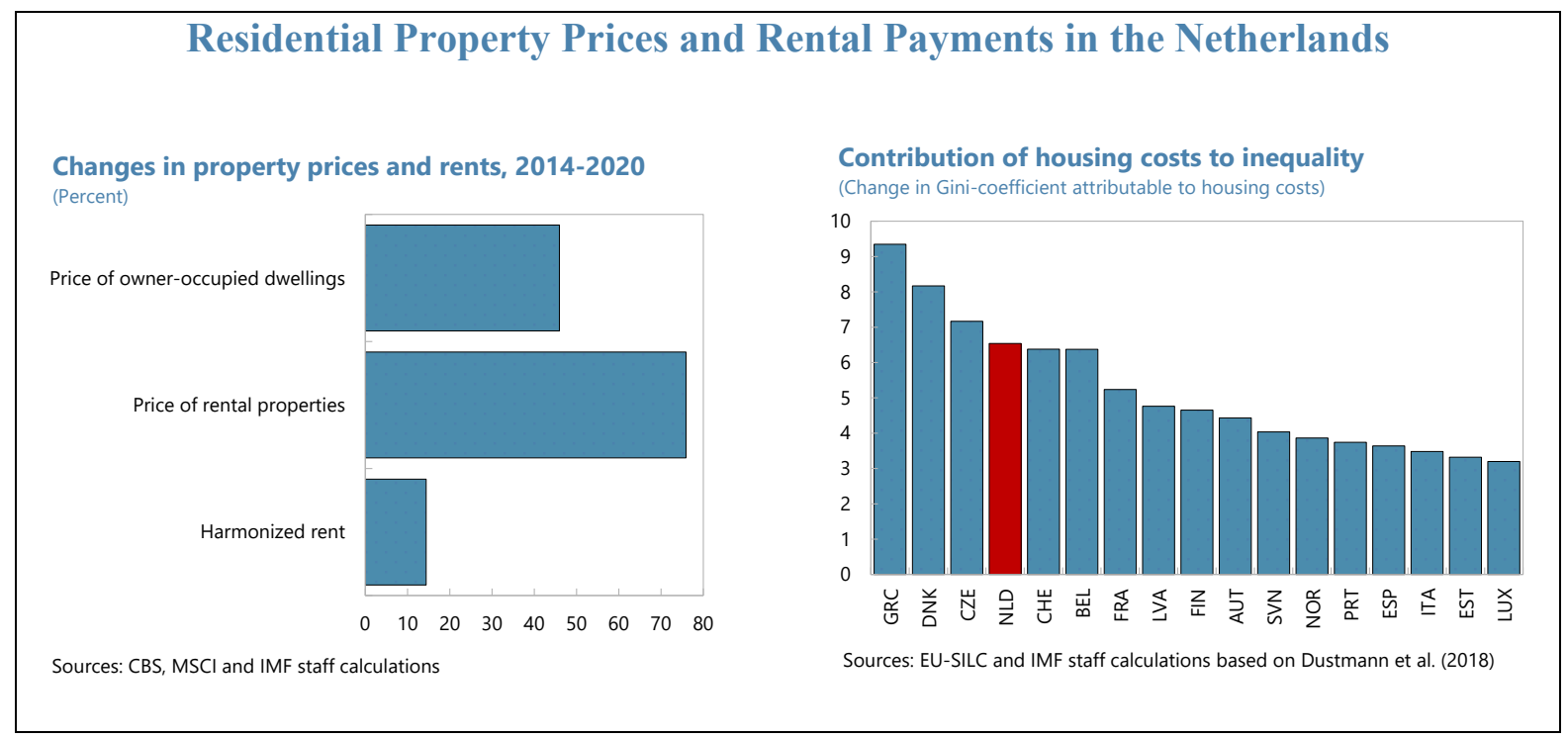

Against this background, the following analysis aims to identify current risks and challenges for Dutch real estate, also to pinpoint areas of possible policy action. Section B provides an overview of the characteristics of the CRE market in the Netherlands, also portraying its participants and highlighting factors limiting its study. Section C outlines recent CRE market developments and potential vulnerabilities, also in the context of the Covid-19 crisis. Section D turns to RRE markets, describing their structure and touching upon macro-financial as well as socio-economic challenges. Section E draws some conclusions and offers policy recommendations.

\footnotetext{
${ }^{4}$ Price-to-income ratios are an imperfect indicator of housing affordability since they ignore the impact of financing costs. However, households in other euro area countries are likely to encounter mortgage rates that are comparable to those in the Netherlands. Therefore, price-to-income ratios still provide a measure of affordability pressures in relative terms.
} 


\section{B. CRE market characteristics and participants}

Exposure to CRE risk can take multiple forms, as property, investor and investment types are characterized by considerable variety. CRE can encompass buildings as distinct as hospitals, hotels, housing for the elderly, industrial premises, offices, shopping malls, single store retail or warehouses. Likewise, a sizeable number of financial market participants are maintaining portfolios subject to CRE risk, comprising banks, institutional investors (pension funds, insurance companies, real estate investment funds and trusts), holders of debt collateralized by CRE or buyers of equity and bonds issued by firms active in a CRE-related line of business, such as construction companies or purveyors of real estate services. A final source of diversity is the way by which exposure to CRE may be gained, ranging from the direct purchase of physical structures, indirect investment via an array of financial instruments and vehicles to the provision of credit.

\section{Analyzing the many facets of CRE is complicated by the lack of a clear delineation of} the market and substantial data limitations. At the most basic level, a harmonized classification of land and properties as CRE is still to be arrived at, with different definitions in use by private actors and public sector bodies. Typically, buildings that are held with the intention of creating a stream of income for their owners are categorized as CRE. However, residential properties that are not owner-occupied are not classified consistently with private market participants generally subsuming multi-family dwellings under CRE. ${ }^{5}$ By contrast, some European institutions characterize rental housing as RRE. ${ }^{6}$ In addition, information about CRE pricing, transactions and exposures can be patchy with aggregators of standardized datasets going only some way to remedying shortcomings. For instance, MSCI, a provider of property price indicators relied on for some of the analysis in this paper, covers only a fraction of the CRE market, as it counts on assets managers to voluntarily report their portfolios and sets detailed inclusion criteria to ascertain the quality of its indices, thereby limiting the usefulness of its data for drawing conclusions across different countries and CRE segments. ${ }^{7}$

Keeping data limitations in mind, the Dutch CRE market seems relatively large with a higher proportion of residential properties than some euro area peers. As a percent of GDP, the capital value of Dutch CRE reported by MSCI exceeded 7 percent in 2020, in line

\footnotetext{
${ }^{5}$ See, for example, CBRE (2021).

${ }^{6}$ Mehrhoff (2017), while also offering a concise overview of some of the methodological questions, points out that in the EU the delineation of CRE by the ESRB differs from the definitions employed in the Capital Requirements Regulation (CRR) and the ECB Regulation on AnaCredit (analytical credit dataset). ESRB (2016) excluded buy-to-let-housing from CRE but was amended by ESRB (2019) to define CRE as “....any income-producing real estate, either existing or under development, including rental housing; ...”. Still, EIOPA classifies residential buildings used for investment as RRE in its insurance statistics.

${ }^{7}$ For further details, see MSCI (2019) and MSCI (2021). Other information providers, such as Real Capital Analytics or StiVAD, face shortcomings similar to MSCI data and/or do not allow a cross-country comparison.
} 
with France but considerably above the level in Belgium, Germany, Italy and Spain. ${ }^{8}$ In addition, MSCI data indicate residential properties forming the bulk of the CRE universe in the Netherlands, in contrast to other euro area countries that are dominated by the office segment. ${ }^{9}$ Besides, buildings of retail and industrial use are generally a smaller share of the market than in peer economies.

\begin{tabular}{|c|c|c|c|c|c|c|c|}
\hline \multicolumn{8}{|c|}{ Size and Structure of Commercial Real Estate Markets in 2020} \\
\hline & & Netherlands & Belgium & France & Germany & Italy & Spain \\
\hline$\overline{\text { Total capital value }}$ & $\overline{(E U R ~ b n)}$ & 61.2 & 8.4 & 183.1 & 101.4 & 29.0 & 22.0 \\
\hline Total capital value & (percent of GDP) & 7.7 & 1.9 & 8.0 & 3.0 & 1.8 & 2.0 \\
\hline Retail & (percent of total capital value) & 13.7 & 18.6 & 12.8 & 19.5 & 23.1 & 23.9 \\
\hline Office & (percent of total capital value) & 12.0 & 66.0 & 61.5 & 47.7 & 50.6 & 47.1 \\
\hline Industrial & (percent of total capital value) & 8.5 & 8.7 & 7.7 & 11.6 & 12.9 & 12.7 \\
\hline Residential & (percent of total capital value) & 60.3 & $\ldots$ & 10.6 & 13.1 & 3.7 & 12.4 \\
\hline Hotel & (percent of total capital value) & 1.8 & 1.7 & 1.6 & 4.0 & 3.2 & 2.2 \\
\hline Other & (percent of total capital value) & 3.6 & 5.1 & 5.7 & 4.1 & 6.5 & 1.7 \\
\hline
\end{tabular}

\section{Apart from Dutch banks, non-bank financial institutions, like insurance companies, pensions funds and investment funds, also maintain notable CRE portfolios. At 20} percent of GDP, the exposure to CRE risk in the balance sheets of banks in the Netherlands ranks among the highest in the euro area. Among non-bank financial institutions, CRE is an equally popular investment with the asset class usually taking a higher share of portfolios than in Belgium, France, Germany, Italy and Spain. Specifically, Dutch occupational pension funds allocate nearly 14 percent of their assets to real estate, substantially more than their peers in other euro area countries. ${ }^{10}$ Similarly, the proportion of investment funds with a real estate mandate is sizable, accounting for more than 13 percent of total investment fund assets. However, portfolio allocations to physical structures (non-financial assets) by Dutch real estate investment funds seem lower than in peer economies, revealing some preference for more liquid assets and geographical diversification, provided by equities of firms and other investment funds active in the real estate business. ${ }^{11}$ Finally, insurance companies in the Netherlands show a relatively small prevalence of CRE in their asset structure. Nevertheless, some of their significant residential real estate holdings may be classified as CRE were EIOPA to follow conventional CRE definitions. Taken together, the sensitivity of the Dutch financial sector to CRE price and investment cycles appears considerable, and more so than

\footnotetext{
${ }^{8}$ The capital value of a property is defined as the estimated price that would be received to sell an asset in an orderly transaction between market participants, net of transaction costs.

${ }^{9}$ Real Capital Analytics, however, reports a notably smaller share of residential properties than MSCI.

${ }^{10}$ Whereas land and buildings are likely to represent CRE, some mortgages and other loans may be related to the owner-occupied properties of households, thereby not meeting the commonly applied definition of CRE.

${ }^{11}$ Some assets of investment funds may constitute exposures to residential real estate, like debt securities collateralized by residential mortgages, the equity of companies mainly active in the residential real estate market or mortgage loans.
} 
in other euro area countries, warranting close monitoring by regulators and supervisors in order to address any build-up of risks at an early stage. ${ }^{12}$

\begin{tabular}{|c|c|c|c|c|c|c|c|}
\hline \multicolumn{8}{|c|}{ Commercial Real Estate Exposures by Non-Bank Financial Institutions } \\
\hline \multicolumn{8}{|l|}{ Insurances } \\
\hline & & $2020 Q 4$ & $2020 Q 4$ & $2020 Q 4$ & $2020 Q 4$ & $2020 Q 4$ & $2020 Q 4$ \\
\hline Total assets & (EUR bn) & 485 & 353 & 2742 & 2380 & 1033 & 308 \\
\hline Total assets & (percent of GDP) & 60.7 & 78.2 & 120.2 & 71.3 & 62.6 & 27.5 \\
\hline Real estate assets & (percent of total assets) & 17.8 & 12.3 & 8.2 & 8.6 & 3.5 & 4.3 \\
\hline Residential real estate & (percent of total assets) & 12.3 & 5.3 & 0.4 & 3.0 & 0.1 & 0.1 \\
\hline Commercial real estate & (percent of total assets) & 1.9 & 3.3 & 1.2 & 2.4 & 0.6 & 3.1 \\
\hline General exposure & (percent of total assets) & 0.4 & 2.0 & 0.9 & 0.8 & 0.3 & 2.0 \\
\hline Indirect exposure & (percent of total assets) & 1.4 & 0.9 & 0.1 & 1.3 & 0.1 & 0.0 \\
\hline Own use & (percent of total assets) & 0.1 & 0.4 & 0.2 & 0.3 & 0.2 & 1.1 \\
\hline Unassigned & (percent of total assets) & 3.6 & 3.6 & 6.7 & 3.2 & 2.8 & 1.1 \\
\hline \multicolumn{8}{|l|}{ Occupational pension funds } \\
\hline & & 2019 & 2019 & 2019 & 2019 & 2019 & 2019 \\
\hline Total assets & (EUR bn) & 1570 & 37 & $\ldots$ & 259 & 151 & 37 \\
\hline Total assets & (percent of GDP) & 193.7 & 7.7 & $\ldots$ & 7.5 & 8.4 & 2.9 \\
\hline Land and buildings & (percent of total assets) & 9.4 & 0.2 & $\ldots$ & 3.0 & 1.2 & 0.2 \\
\hline Real estate UCITS & (percent of total assets) & $\ldots$ & 1.0 & $\ldots$ & 3.3 & 0.9 & 0.4 \\
\hline Mortgage and other loans & (percent of total assets) & 4.2 & 0.2 & $\ldots$ & 1.0 & 0.0 & 0.0 \\
\hline \multicolumn{8}{|l|}{ Investment funds } \\
\hline & & 2020 & 2020 & 2020 & 2020 & 2020 & 2020 \\
\hline Total assets & (EUR bn) & 1032 & $\ldots$ & 1513 & 2719 & 407 & 319 \\
\hline Total assets & (percent of GDP) & 159.5 & $\ldots$ & 75.9 & 106.8 & 24.9 & 28.8 \\
\hline Real estate investment funds & (percent of total assets) & 13.5 & $\ldots$ & 10.1 & 13.2 & 23.9 & 0.6 \\
\hline Deposits and loans & (percent of total assets) & 0.6 & $\ldots$ & 0.4 & 1.9 & 1.3 & 0.0 \\
\hline Debt securities & (percent of total assets) & 0.0 & $\ldots$ & 0.2 & 0.1 & 0.0 & 0.0 \\
\hline IFs & (percent of total assets) & 2.8 & $\ldots$ & 0.4 & 0.6 & 1.2 & 0.0 \\
\hline Equity & (percent of total assets) & 5.4 & $\ldots$ & 2.4 & 0.5 & 0.8 & 0.0 \\
\hline Non-financial assets & (percent of total assets) & 4.5 & $\ldots$ & 5.9 & 7.0 & 19.7 & 0.5 \\
\hline Other assets & (percent of total assets) & 0.1 & $\ldots$ & 0.8 & 3.1 & 5.8 & 0.1 \\
\hline
\end{tabular}

\section{In addition, the Dutch CRE market appears highly internationalized, opening an} avenue for cross-border spillovers from globally synchronized property price dynamics. Klapwijk et al. (2017) estimate that about a third of commercial properties in the Netherlands were held by foreigners in 2016. Likewise, CBRE (2021) indicates that since 2013 more than half of investment flowing into Dutch CRE has originated abroad, replacing domestic investors who prevailed over the period 2007-2012. In turn, insurers and pension funds based

\footnotetext{
${ }^{12}$ Summing up the individual CRE exposures of banks, insurance companies, pension funds and investment funds may, in a way, involve some degree of double-counting as some entities achieve their desired portfolio allocations by indirect means, such as when an insurance company invests in a real estate investment fund. Klapwijk et al. (2017) try to quantify the effect, estimating that, in 2016, nearly half of Dutch CRE was held by investment funds which in turn featured Dutch pensions funds and insurances as their clients. Even though such interlinkages reduce total financial sector CRE exposures on a net basis, they introduce additional complexity, potentially providing fertile ground for intra-sectoral spillovers.
} 
in the Netherlands hold internationally diversified CRE portfolio ${ }^{13}$ while banks have substantially pared back their cross-border CRE exposures in recent years. ${ }^{14}$ Thus, CRE in the Netherlands does not only appear sensitive to domestic developments but also to factors driving CRE markets at a global level. At the same time, increasing synchronization of real estate prices across countries may undermine some of the benefits of international diversification, such as access to a wider pool of funding and investment opportunities, while also raising the risk of amplifying the CRE cycle in the Netherlands and transmitting fluctuations in foreign CRE markets to the Dutch financial sector. ${ }^{15}$

\section{CRE market developments and vulnerabilities}

\section{Following a bust after the global financial crisis, Dutch CRE has seen a strong revival that has been only moderately dampened by the Covid-19 crisis. After a period of rather} subdued investment volumes in 2009-2015, interest in CRE has picked up substantially since 2016 , broadly in line with developments in the euro area. Even in 2020, flows into CRE properties remained above the peak seen before the global financial crisis, despite the economic disruptions triggered by the Covid-19 pandemic. Residential properties have proven particularly popular during the current cycle whereas retail, apart from a brief spike in 2017, attracted little attention. Moreover, the segment of industrial buildings, such as warehouses or production facilities, has grown in importance over time, possibly also indicating the rising logistical needs of businesses engaging in e-commerce. Trends in investment flows have been reflected in CRE prices with residential properties witnessing steep increases while the value of office and industrial premises has climbed after troughing in the mid-2010s. Remarkably, the recession of 2020 appears to have had little impact on CRE prices so far, apart from retail where the crisis seems to have accelerated a pre-existing downward trend.

\footnotetext{
${ }^{13}$ See DNB (2018). EIOPA data indicate that more than a quarter of assets designated as commercial real estate by Dutch insurers were held abroad at the end of 2020 .

${ }^{14}$ ECB data show that about a fifth of bank exposures collateralized by immovable commercial property were held outside the Netherlands in 2019, compared to more than two thirds in 2014.

${ }^{15}$ BIS (2020) provides evidence for a rise in the co-movement of property prices across countries since the global financial crisis. Francke and van Dijk (2021) show that benefits from internationally diversified CRE portfolios may be hard to obtain in the presence of a pronounced global liquidity cycle.
} 


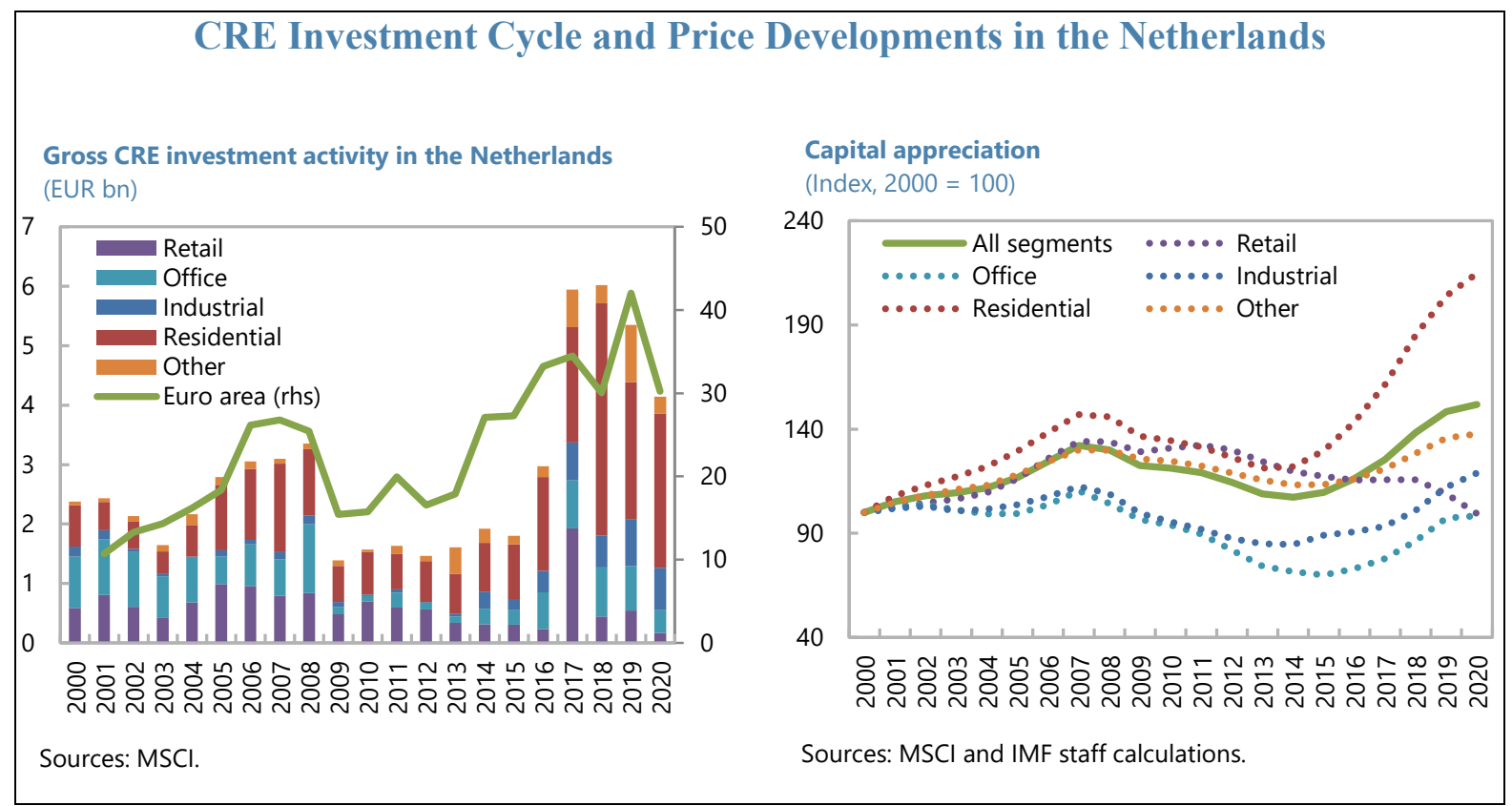

As a result of ongoing price rises, valuations have become more stretched, particularly in the context of a pick-up in vacancies and depressed yields for safe assets. Although largely staying far below the rates seen at the height of the euro area sovereign debt crisis in 2012, vacancies increased as a consequence of the economic fallout from the Covid-19 pandemic, thereby weighing on rental income expectations. Again, retail showed the most marked deterioration with vacancy rates in 2020 far exceeding their 2012 levels. Nevertheless, valuations have continued to climb, raising the risk of a correction if the rebound in economic activity after the pandemic does not translate into a corresponding recovery of CRE rents. ${ }^{16}$ Moreover, an increase in the yields offered by other assets classes may put pressure on CRE valuations since they presently appear to be at least in part supported by the depressed returns of safer alternatives.

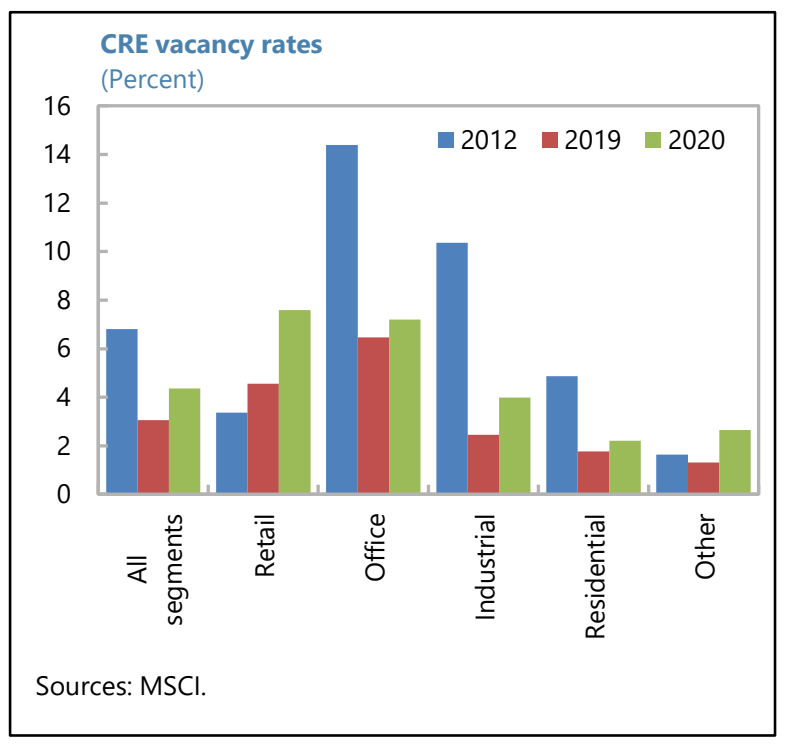

Aside from valuations, structural changes in some segments of the CRE market, potentially reinforced by the Covid-19 pandemic, remain a concern. Even though digital penetration in the Netherlands ranks among the highest in the euro area, implying that some of its impact on the CRE market has already run its course, more may yet be in store. Despite

\footnotetext{
${ }^{16}$ Indeed, DNB (2021a) concludes that the drop in the marketability of CRE properties seen in 2020 could be a harbinger of price corrections to come.
} 
making the most use of telecommuting in the euro area, slightly more than 60 percent of Dutch employees do not engage in working from home, possibly implying additional potential to economize on office space, particularly after the experience of the Covid-19 pandemic has demonstrated its viability. As a result, some offices may become harder to let or may even become obsolete, depressing valuations. Turning to retail properties, online sales in the Netherlands expanded at a rapid clip between 2004 and 2019, reaching average annual growth rates of nearly 10 percent, substantially above the pace in other euro area economies, and lifting the share of households who have purchased online beyond 80 percent. As a corollary, vacancy rates of retail properties have steadily risen in recent years with prices and valuations lagging other CRE segments (see also charts above). Like for offices, the current crisis may therefore contribute to the acceleration of structural shifts that have already been underway in the retail segment of the CRE market. Most notably, closures of brick-and-mortar shops during the Covid-19 pandemic have given another push to ecommerce with online sales growing in the high double-digits in 2020. Moreover, business travel may fail to fully recover if remote interactions will substitute for some in-person exchanges in the future, affecting parts of the retail and hotel industry. Such changes could particularly affect the Netherlands which, even if not one of the prime tourism destinations in the euro area, records a relatively large share of people travelling to the country for professional reasons.

\begin{tabular}{|c|c|c|c|c|}
\hline & \multicolumn{4}{|c|}{$\begin{array}{c}\text { Real retail sales } \\
\text { (average annual percentage growth) }\end{array}$} \\
\hline & \multicolumn{2}{|c|}{$2004-19$} & \multicolumn{2}{|c|}{2020} \\
\hline & $\begin{array}{c}\text { excl. } \\
\text { vehicles } \\
\text { and fuel }\end{array}$ & $\begin{array}{l}\text { mail order } \\
\text { and } \\
\text { internet }\end{array}$ & $\begin{array}{c}\text { excl. } \\
\text { vehicles } \\
\text { and fuel }\end{array}$ & $\begin{array}{c}\text { mail order } \\
\text { and } \\
\text { internet }\end{array}$ \\
\hline Netherlands & 0.7 & 9.6 & -4.2 & 30.6 \\
\hline Belgium & 0.8 & 3.6 & 4.4 & 57.7 \\
\hline France & 2.8 & 5.1 & 10.6 & 32.3 \\
\hline Germany & 1.1 & 5.3 & 0.1 & 27.5 \\
\hline Italy & -0.5 & 3.5 & -6.3 & 33.9 \\
\hline Spain & -0.9 & 4.6 & 4.6 & 41.5 \\
\hline Euro area & 0.9 & 5.0 & 1.2 & 28.3 \\
\hline
\end{tabular}




\section{Digital Penetration and Business Travel}

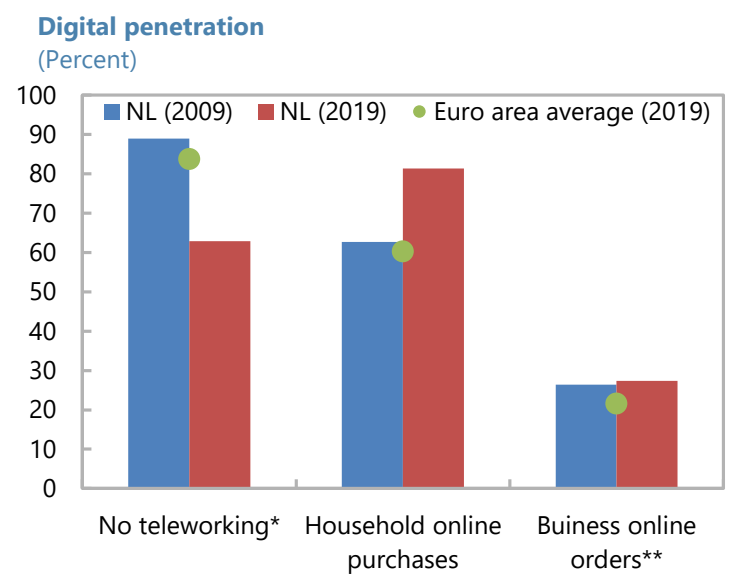

Sources: Eurostat, OECD and IMF staff calculations.

* share of employees not engaged in any teleworking.

** share of businesses receiving orders via computer networks.

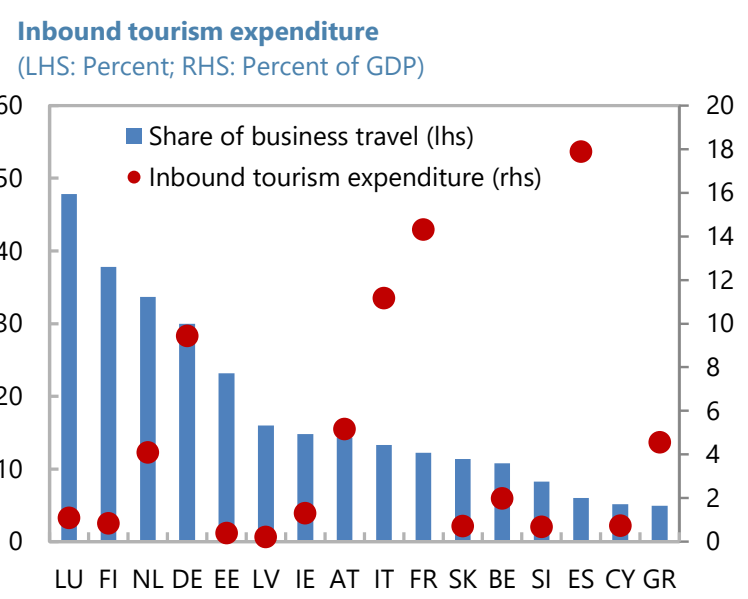

Sources: UNWTO, national authorities and IMF staff calculations.

Notes: All data refer to 2019 with the exception of DE, LU and NL where only 2018 figures are available.

\section{Developments in CRE markets have the capacity to affect financial stability and the} wider economy via several channels. Most obviously, the souring of exposures by banks and non-bank financial institutions may burden balance sheets and capital positions. In addition, tighter funding conditions on the back of a deteriorating quality of CRE-related assets and associated losses by investors may dampen economic activity, particularly if amplified by factors such as waning construction output or heightened financial market volatility. Moreover, spillovers across sectors or borders resulting from the panoply of entities active in the market and their various interlinkages are contributing a further layer of complexity. Finally, lasting structural changes experienced by several CRE segments in recent years, such as the encroachment of e-commerce on bricks-and-mortar retail, have complicated the monitoring of risks, the assessment of vulnerabilities and the appropriate calibration of policy measures. ${ }^{17}$

\footnotetext{
${ }^{17}$ For an overview of possible transmission channels from the CRE market to the financial sector and the real economy, see for example IMF (2021a), pp. 51-74, or ESRB (2018), pp. 17-20.
} 
Elevated CRE valuations coupled with pandemic-related market weakness and secular adjustment may put strains on the financial system. Although banks have reduced their CRE portfolios in recent years, particularly abroad, exposures remain high and the quality of CRE-related loans is generally worse than that of claims on other borrowers. Likewise, possible losses on assets linked to the performance of CRE that are held by insurance companies and pension funds in the Netherlands may aggravate some of the pressures they are already facing from low interest rates and an ageing society. Lastly, leverage ${ }^{18}$ among real estate investment funds, even if on a declining trend since the global financial crisis, has stayed elevated, raising risks of fire sales of - potentially illiquid - assets should debt financing dry up. Stress tests performed by DNB (2020a) on banks, and extended by DNB (2021b) to insurers and pension funds, indicate notable CRE-related losses under the rather adverse assumptions adopted against the background of the Covid-19 pandemic. Especially exposures to the retail and office segment would suffer while the impact on industrial and residential properties, albeit significant, appears more contained. As a result, the capital cushions of banks and insurance companies would deteriorate but remain at relatively comfortable levels. The funding ratios of many pension funds, already in breach of regulatory minima in recent years, would worsen further, reflecting the rather high share of CRE assets in their portfolios as well as their sensitivity to macroeconomic shocks.

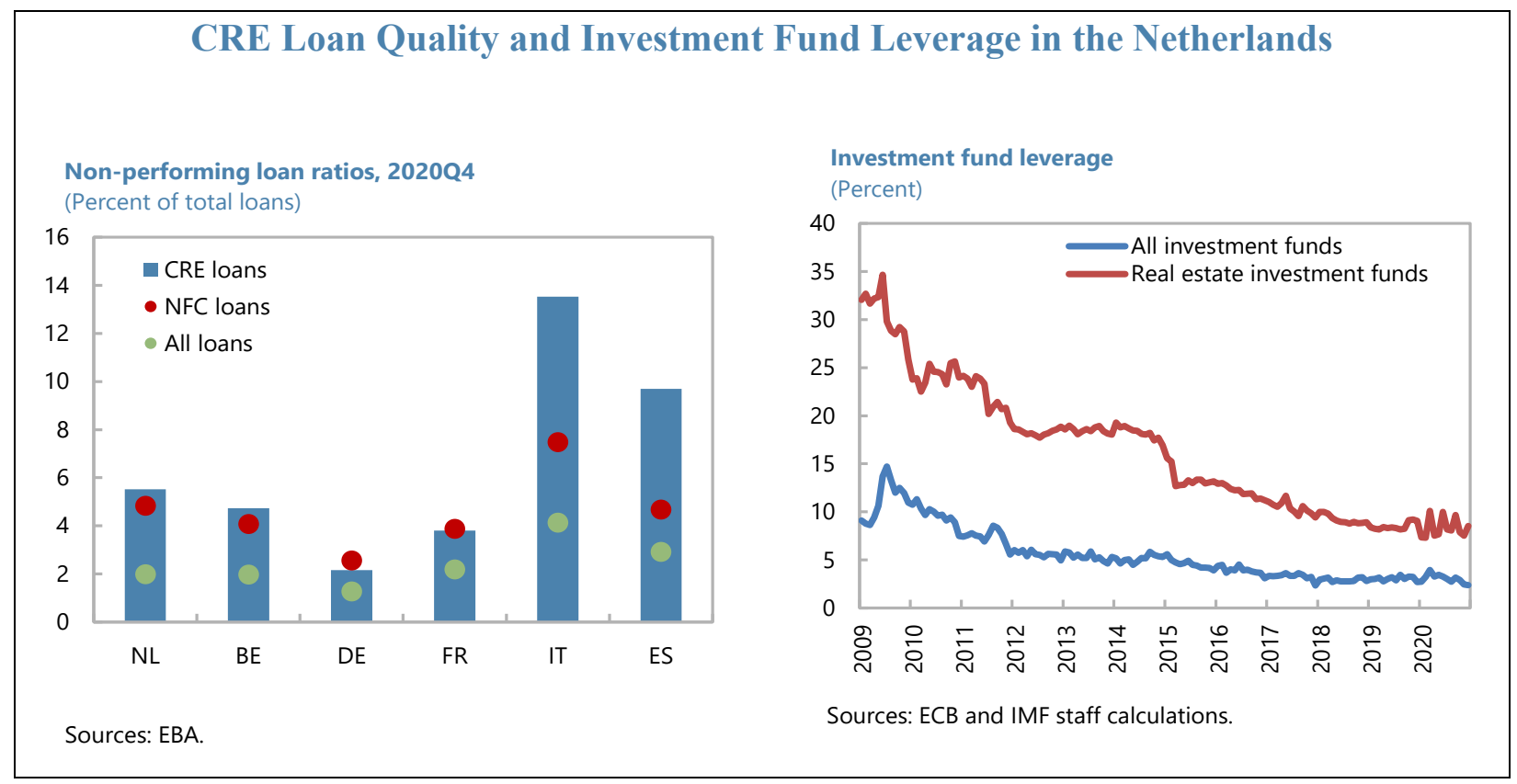

\footnotetext{
${ }^{18}$ Due to data limitations, leverage must be understood as a relatively broad concept here, encompassing all liabilities on the balance sheets of investment funds that are not equity-type units held by investors, which may include financing that does not constitute debt.
} 


\section{RRE market characteristics and challenges}

RRE in the Netherlands is characterized by a prevalence of residents living in rental units and the vast majority of owner-occupied dwellings carrying a mortgage. Among European economies, the Netherlands maintains one of the highest shares of occupants living in rental accommodation. At the same time, the provision of social housing is widespread with more than a third of the building stock offering below-market rents. In the owneroccupied segment, the fraction of residences without mortgages is one of the smallest in comparison to other European countries with just slightly more than a tenth of dwellings free of debt.

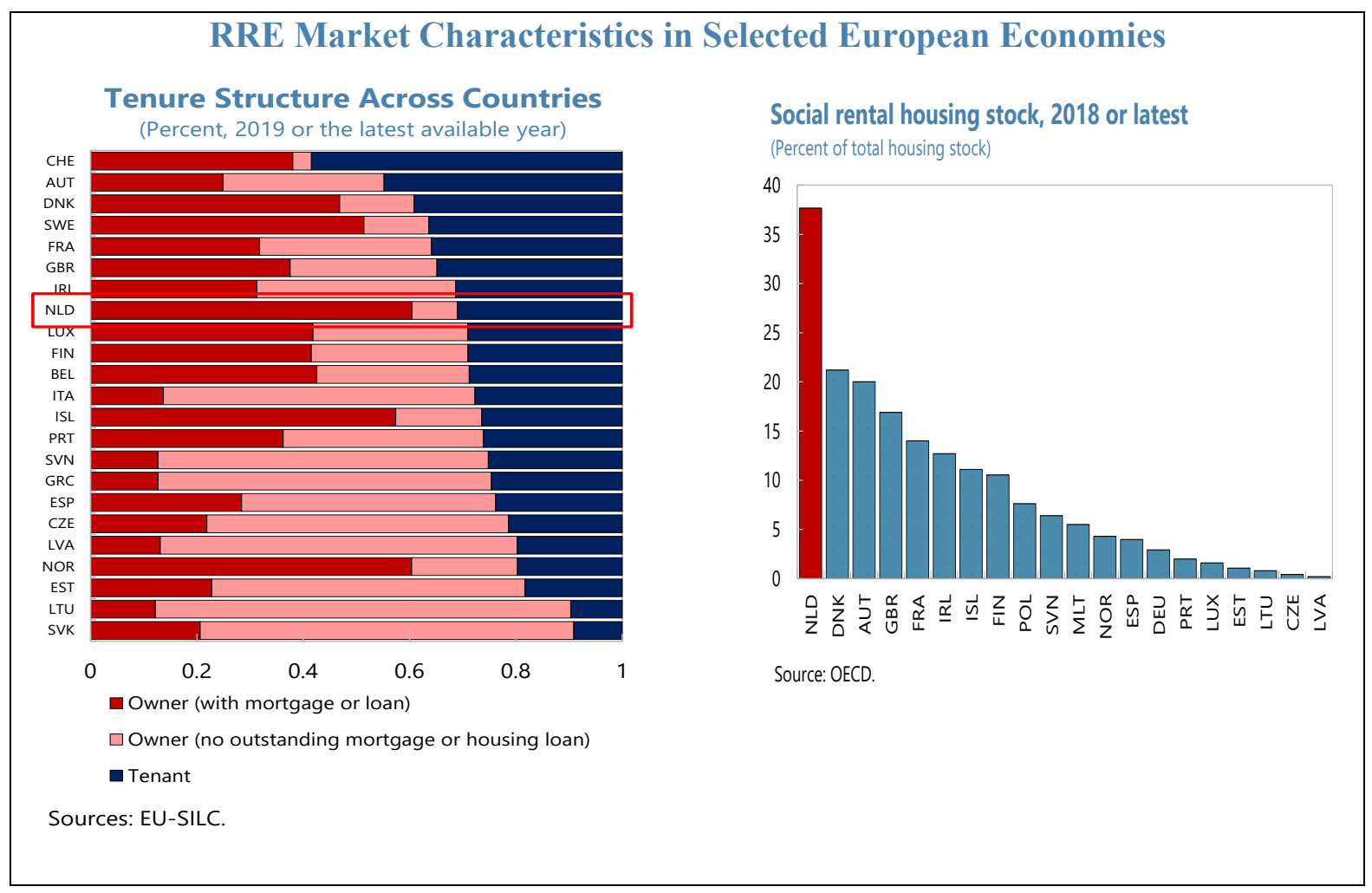

Together with emerging signs of RRE overvaluation, the substantial indebtedness of Dutch households contributes to macro-financial vulnerabilities. Despite a small uptick in 2020, the ratio of non-performing to total mortgages ranks as one of the lowest in the euro area, in part supported by a fall in the share of high loan-to-value or negative equity borrowings on the back of rising RRE prices and macroprudential measures implemented by the authorities in the wake of the global financial crisis. However, valuations of RRE have become elevated in recent times, even if they remain below their 2007 peaks. ${ }^{19}$ In addition, the debt burden of households in the Netherlands has stayed significantly above its peers in the euro area with high savings likely providing a rather limited cushion due to their lack of

\footnotetext{
${ }^{19}$ For more details about the methodology employed to estimate RRE valuations, see ECB (2011) and ECB (2015).
} 
liquidity. Consequently, a turn in the housing cycle has the potential to weaken the balance sheet strength of the Dutch financial system, either directly, by eroding the quality of mortgage exposures, or indirectly, by dampening economic activity as households reallocate consumption expenditures to debt repayments, although the ability of borrowers to finance at advantageous mortgage rates for long maturities in recent years may dampen the impact on spending. ${ }^{20}$ Moreover, the phase-out of pandemic-related support could put near-term pressure on the ability of some households to service their debt while mounting maturities of interest-only mortgages in the late 2020 s and 2030s may constitute a long-term risk. ${ }^{21}$

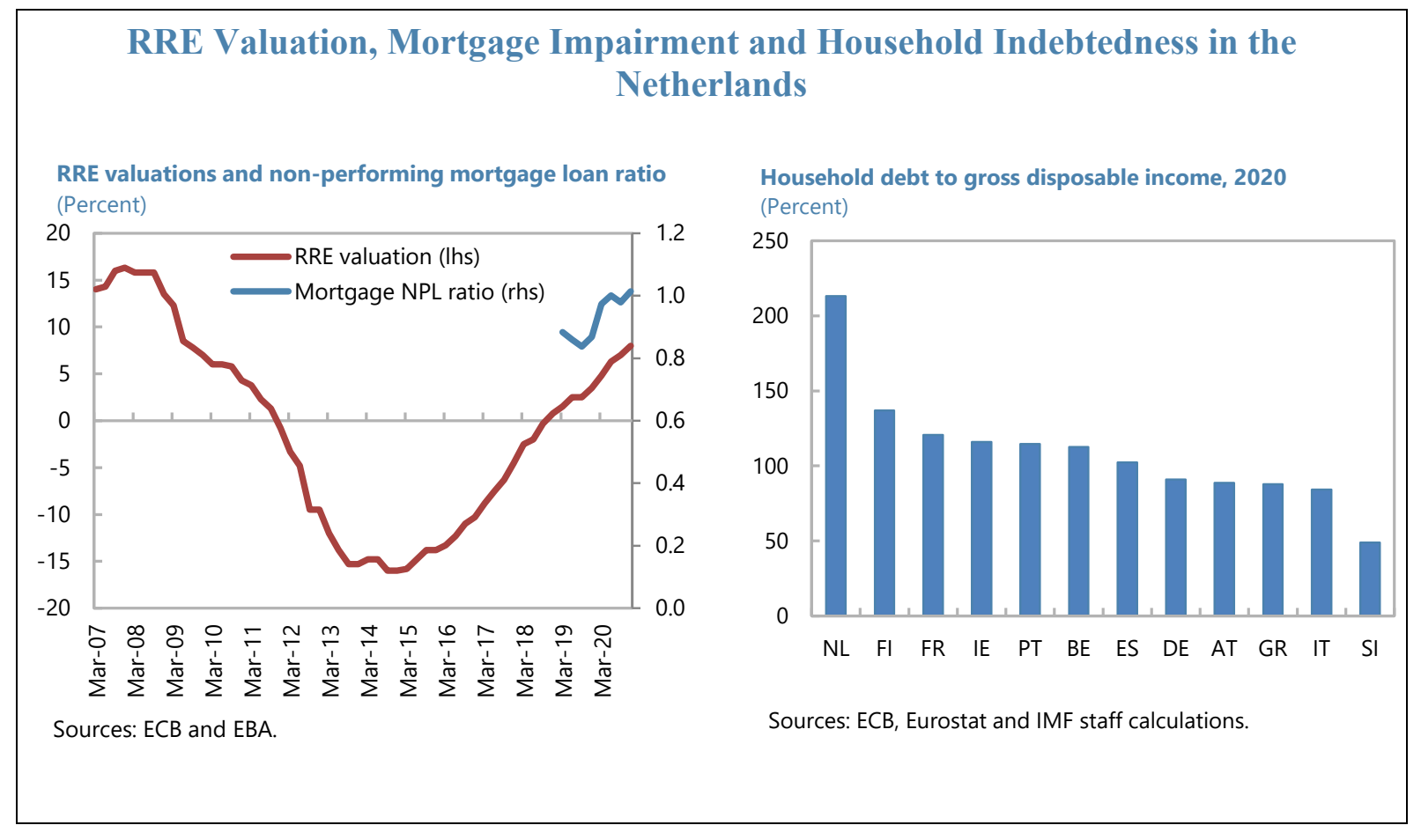

The Dutch income tax system has long had embedded incentives and arbitrage opportunities toward homeownership indebtedness. ${ }^{22}$ Personal income is classified into so-called "Boxes" and taxed at different rates depending on the source of earnings: in Box 1,

\footnotetext{
${ }^{20}$ Lenders in the Netherlands have full legal recourse on mortgage borrowers, creating strong incentives to service rather than default on debt. In the wake of the global financial crisis, mortgage NPLs remained comparatively stable, despite a substantial decline in house prices. Stress tests performed in DNB (2020b) in the context of the pandemic indicate that losses for the mortgage portfolios of Dutch banks are comparatively limited while noting that a long-lasting downturn in housing markets may have a more tangible impact on the balance sheets of banks. In addition, the National Mortgage Guarantee, insuring mortgage repayments of EUR $22.6 \mathrm{bn}$ as at the end of 2019, mitigates some of the credit risk for the financial sector.

${ }^{21}$ According to AFM (2021), about half of mortgages in the Netherlands are non-amortizing debt with maturities peaking in the mid-2030s. However, a scenario analysis performed be the authors is pointing towards a manageable risk of debt distress among borrowers with interest-only loans.

${ }^{22}$ For an early treatment of the issue and its implications for the pricing of owner-occupied housing, see for example Kakes et al. (2002).
} 
active income from salaries, self-employment, equity and similar sources is taxed at progressive rates up to a maximum of 49.5 percent in 2021. In Box 2, labor and capital income from closely held companies is taxed at a flat rate of 26.9 percent. In Box 3 , capital income is subject to a flat rate of 31 percent applied on a deemed remuneration (estimated income) from net assets rather than on actual realized dividends and interest. Income taxable in Box 1 also includes a deemed income (imputed rental income) from ownership of a house that qualifies as primary residence and is calculated on the basis of the market value of the property as assessed by municipal authorities. At the same time, a mortgage interest tax deduction (MITD) from income falling into Box 1 is allowed in relation to the financing, renovation, or maintenance of the primary residence. In practice, the imputed rent has been significantly smaller than the MITD creating a negative income which could be carried back for up to three years to offset other tax liabilities. Moreover, those homeowners who opted for balloon mortgages before 2013 (repaying the principal in full at the end of the loan period) are able to deduct interest on the full mortgage amount for the duration of the loan. As a result, the tax treatment of home ownership incentivizes large mortgage debts and costs about 1.3 percent of GDP in forgone budgetary revenue (OECD 2021).

\section{Structural housing market rigidities are exacerbating the social impact of rising home}

prices and rents. In essence, the Netherlands is subsidizing social and owner-occupied dwellings, by enabling rents at below market-clearing levels for the former and by offering an attractive tax treatment of the latter. By contrast, the private rental market receives no such support, notwithstanding rising demand from segments of the population that are ineligible for social housing but cannot afford or do not wish to purchase a property. ${ }^{23}$ At the same time, a multitude of barriers are hampering the supply of housing in general, and private rentals in particular. For instance, municipalities, which depend on revenues from land development, prefer the construction of owner-occupied buildings as they commonly fetch higher prices than rental structures, also reflecting the higher payment capacity of owners due to their favorable tax treatment. Besides, spatial constraints, in part owing to zoning restrictions, are frequently preventing the expansion of housing, especially in the major cities, and planning capacity has been scaled down following the real estate bust after the global financial crisis. ${ }^{24}$ As a consequence, the median Dutch tenant renting at market prices needs to dedicate a rather large share of its disposable income to accommodation in relation to European peers, with the poorest quintile likely to be overburdened. ${ }^{25}$

\footnotetext{
${ }^{23}$ Findings by Ministerie van Binnenlandse Zaken en Koninkrijksrelaties (2016) indicate that a small but growing share of tenants prefer renting to owning a property. Boumeester and Dol (2016) attribute such shifts to structural changes in labor markets, such as more flexible working arrangements.

${ }^{24}$ For an extensive overview of factors preventing the supply of (rental) housing in the Netherlands, see DNB (2017).

${ }^{25}$ Tenants are commonly judged to be overburdened if they spend more than 40 or, more conservatively, 30 percent of their disposable income on rent. For an overview of alternative housing affordability measures, see for example Ezennia and Hoskara (2019).
} 


\section{By unevenly affecting different strata of the population, the pandemic has} probably sharpened existing housing-related inequalities. The weight of the recession triggered by the Covid-19 crisis has been disproportionately shouldered by more vulnerable groups. IMF (2021b) shows that particularly the young and the lower-skilled have experienced considerably larger increases in unemployment than older and better educated parts of the citizenry. Conversely, these groups align relatively closely with segments of the public who are most likely to rent and for whom buying a property or coping with rising rental costs is challenging as a result of insufficient savings or income. ${ }^{26}$ Even though some of the effects of the pandemic may contribute to a lessening of upside pressures on rents, such as a potential reduction in tourism and business travel or a migration away from urban centers on the back of remote working, their impact appears rather uncertain at present and seems unlikely to provide much immediate relief for a housing market as tight as the Netherlands'. ${ }^{27}$

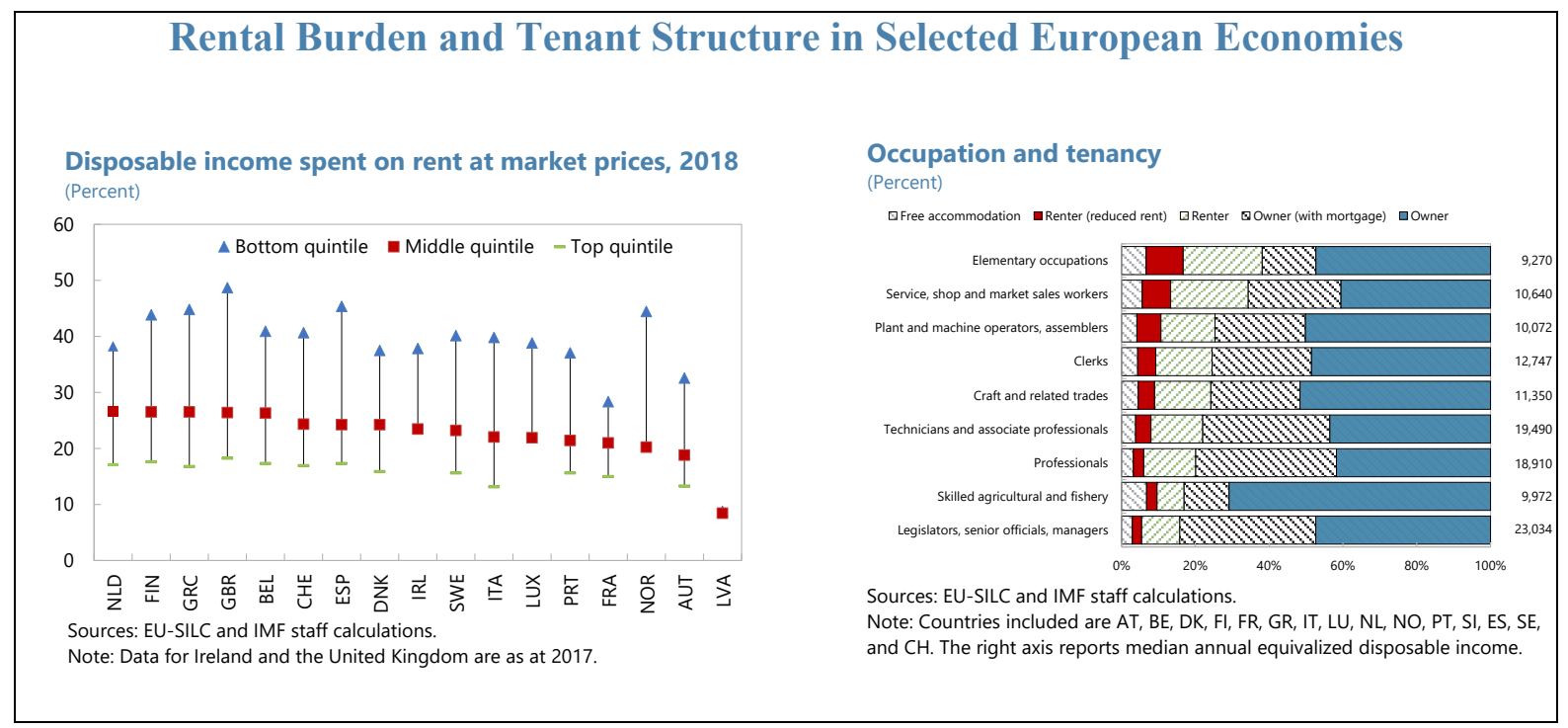

\section{E. Conclusions and policy recommendations}

The Dutch economy faces notable real estate-related challenges, both from a macrofinancial and from a socio-economic perspective. At present, real estate valuations appear elevated, particularly when considering the economic disruptions brought on by the Covid-19 pandemic. At the same time, real estate constitutes a sizeable share in the portfolios of Dutch banks, insurance companies, pension funds and investment funds. As a consequence, risks for macro-financial stability from a protracted, and potentially synchronized, downturn in RRE and CRE markets appear elevated. Moreover, Dutch CRE and RRE are each facing

\footnotetext{
${ }^{26}$ See also IMF (2021c).

${ }^{27}$ DNB (2017) highlights short-term rentals, such as Airbnb, as a factor for the shortage of rental offers in tourist hotspots, such as Amsterdam. Furthermore, unused hotel capacity may present some potential for conversion into residential dwellings.
} 
their own set of unique issues. CRE has been subject to far-reaching structural change in recent years, in part accelerated by the current crisis, affecting the long-term appeal and viability of some classes of buildings. RRE is characterized by a shortage of affordable housing options outside the social rental segment, particularly for vulnerable segments of the population hit hardest by the recession, possibly providing fertile ground for social tension and slowing post-pandemic resource reallocation.

\section{In recent years, the authorities have shown heightened awareness for the risks and weaknesses of Dutch real estate markets and have taken appropriate policy action.}

Specifically, legally binding limits on debt-service-to-income and loan-to-value ratios were introduced in January 2013, with the latter dropping by 1 percentage point per year until it reached 100 percent in 2018. In addition, eligibility for MITD on new mortgages has been limited from January 2014 to loans amortized over 30 years or less, while the MITD rate was put on a declining path, shrinking by 0.5 percentage point per year initially. Thus, it fell from 52 percent to 49 percent in 2019. After that, it was set to decline faster, by 3 percentage points per year, starting in 2020, until reaching 37 percent by $2024 .{ }^{28}$ As of 2021, mortgage interest paid can only be deducted against a maximum tax rate of 43 percent. Moreover, the imputed rent in Box 1 is being gradually increased with the intention to offset most of the interest mortgage deduction in the long run. ${ }^{29}$ Finally, the decision by the Dutch central bank to introduce minimum risk weights for mortgage loans, announced in October 2019 but suspended in the context of the pandemic, from 1 January 2022 appears appropriate in view of current developments in housing markets, as is the intention to begin a gradual build-up of countercyclical capital buffers thereafter.

\section{Going forward, a multitude of challenges remains, offering an opportunity for policy makers to shape developments to come.}

- $\quad$ Concerning CRE, data gaps that inhibit appropriate classification, pricing and valuation and prevent the identification of exposures should be addressed. In this regard, ongoing work to advance efforts by international bodies to address such shortcomings at the national level are welcome and should be expedited..$^{30}$

\footnotetext{
${ }^{28}$ The interest paid on mortgage loans contracted from 2013 can only be deducted if the mortgage is fully repaid within a maximum period of 30 years and follows a linear/annuity repayment pattern. For mortgage loans initiated before 2013, interest paid can be deducted for a maximum period of 30 years, irrespective of whether the mortgage loan is amortized during this period (see https:/www.rijksoverheid.nl/onderwerpen/huiskopen/vraag-en-antwoord/recht-op-hypotheekrenteaftrek).

${ }^{29}$ As of 2021, the deemed income is generally calculated as 0.50 percent of the estimated market value of the house which is also the base for the municipality property tax; for properties worth more than EUR 1.11 million, a rate of 2.35 percent is applied to the value exceeding this threshold (see https://taxsummaries.pwc.com/netherlands/individual/deductions).

${ }^{30}$ For more detail about efforts by European institutions to identify and work towards closing CRE-related data gaps, see for example ESRB (2016), ESRB (2019a) and ESRB (2019b). At the international level, BIS (2019) or FSB and IMF (2009) and subsequent progress reports provide an overview.
} 
Furthermore, policy tools to counter vulnerabilities emerging from bank and nonbank financial sector exposures to CRE should be in place and deployed in a timely manner when needed. In this context, drawing lessons from RRE by modifying risk weights and capital requirements according to collateral quality, borrower leverage and debt servicing capacity, or the stage of the CRE investment cycle, may be contemplated as an option.

- With respect to RRE, tightening supervisory policies, also by extending their reach to non-bank financial institutions, and reviewing tax design could further reduce the debt bias inherent in the owner-occupied housing market. While loan-to-value ratios have been reduced, employing generous borrowing limits to address affordability issues for e.g. first-time buyers appears second best. Thus, prudential settings should be reviewed with the aim to further discourage riskier forms of mortgage lending. To the same end, a number of reforms to taxation could be considered to arrive at a more level treatment between owner-occupied and rental housing. Keen et al. (2010) note that a fully neutral taxation of owner-occupied housing would require full taxation of imputed rents and capital gains on housing, combined with mortgage interest deductibility. ${ }^{31}$ In practice, however, imputed rents and capital gains on primary residences are rarely taxed, creating a general bias toward housing, which is reinforced by the mortgage interest relief where it exists. The Netherlands is an exception as it taxes imputed rent, yet at a level substantially below its actual value. ${ }^{32}$ Furthermore, the Dutch tax system does not cap the deduction of mortgage interest payments to the lowest marginal tax rates, unlike other countries (see Table).

Gradually raising the value of imputed rents to realistic levels in Box 1 would allow a partial correction to the debt bias and would be easier to implement, yet would not address the incentive for excessive mortgage borrowing while saving in tax-favored vehicles under Box 3 . Shifting the taxation of housing to Box 3 would automatically increase imputed rents and remove the incentive to raise mortgage debt while investing in other financial assets. A broader reform of the tax system would ideally combine the latter option with a reform of Box 3 which would tax actual rather than notional returns..$^{33}$

\footnotetext{
${ }^{31}$ Specifically, taxation of imputed rents - the consumption value of housing services - is needed to match the payment of market rents from taxed income; taxation of capital gains is needed to match the capital gains tax liability on other financial assets; and deductibility of mortgage interest is needed to match the taxation of the interest available from investing in other assets.

${ }^{32}$ Switzerland is another notable example.

${ }^{33}$ For a detailed discussion, see Klemm et al. (2021).
} 


\begin{tabular}{|c|c|c|c|c|c|c|c|c|}
\hline \multicolumn{9}{|c|}{ Mortgage Interest Deductibility in Selected Countries } \\
\hline & Netherlands & Denmark & Finland & Ireland & Norway & Spain & Sweden & $\begin{array}{l}\text { United } \\
\text { Kingdom }\end{array}$ \\
\hline $\begin{array}{l}\text { General } \\
\text { rule }\end{array}$ & $\begin{array}{l}100 \text { percent for } \\
\text { pre-2013 loans; } \\
100 \text { percent for } \\
\text { post-2013 fully } \\
\text { amortizing loans } \\
\text { (within } 30 \text { years) }\end{array}$ & 32.7 percent & $\begin{array}{l}45 \text { percent capital } \\
\text { income deduction } \\
\text { in } 2017 ; 35 \\
\text { percent in } 2018 ; \\
25 \text { percent in } \\
2019 \text { and } \\
\text { thereafter }\end{array}$ & $\begin{array}{l}\text { Sliding scale until } \\
\text { end-2020. Up to } \\
30 \text { percent for } \\
\text { first-time } \\
\text { homebuyers; half } \\
\text { for others. } 1 / 4 \\
\text { nominal reduction } \\
\text { each year }\end{array}$ & $\begin{array}{l}100 \text { percent } \\
\text { (full } \\
\text { deduction) }\end{array}$ & $\begin{array}{l}0 \text { percent for } \\
\text { properties } \\
\text { purchased } \\
\text { after Jan } 1 \text {, } \\
2013\end{array}$ & 30 percent & 0 percent \\
\hline Cap/notes & $\begin{array}{l}\text { The maximum tax } \\
\text { rate that mortgage } \\
\text { interest can be } \\
\text { deducted } \\
\text { decreases by } 3 \\
\text { points annually } \\
\text { from } 2019 \text {, from } \\
\text { around } 50 \text { percent } \\
\text { in } 2018 \text { to } 36.9 \\
\text { percent in } 2025\end{array}$ & $\begin{array}{l}\text { Reduced to } \\
26 \text { percent in } \\
2018 \text { for } \\
\text { annual } \\
\text { mortgage } \\
\text { interest } \\
\text { expense over } \\
\text { DKK 50,000; } \\
25 \text { percent in } \\
2019 \text { and } \\
\text { thereafter }\end{array}$ & $\begin{array}{l}30 \text { percent } \\
\text { deduction of the } \\
\text { excess interest } \\
\text { expense over } \\
\text { capital income } \\
\text { against income } \\
\text { tax, up to EUR } \\
1,400 \text { per year ( } 32 \\
\text { percent for first- } \\
\text { time homebuyers) }\end{array}$ & $\begin{array}{l}\text { Deductibility } \\
\text { varies by } \\
\text { origination date } \\
\text { (only 2004-12), } \\
\text { and borrower's } \\
\text { marital status. All } \\
\text { deductibility } \\
\text { ended on Jan 1, } \\
2021 \text {. }\end{array}$ & & $\begin{array}{l}15 \text { percent } \\
\text { deduction up } \\
\text { to EUR } 9,040 \\
\text { per year, for } \\
\text { properties } \\
\text { purchased } \\
\text { before Dec } \\
31,2012\end{array}$ & $\begin{array}{l}\text { Reduced to } \\
21 \text { percent } \\
\text { for annual } \\
\text { mortgage } \\
\text { interest } \\
\text { expense } \\
\text { over SEK } \\
100,000\end{array}$ & $\begin{array}{l}\text { Mortgage } \\
\text { interest } \\
\text { relief at } \\
\text { source } \\
\text { abolished } \\
\text { in } 2000\end{array}$ \\
\hline
\end{tabular}

- $\quad$ Finally, long-term structural forces shaping real estate markets in the Netherlands are calling for dedicated policies. Rent controls could be loosened and replaced with housing allowances better targeted at tenants in need. To improve the responsiveness of the housing supply, the reasons for - particularly smaller - municipalities to disproportionally focus on the development of owner-occupied housing should be examined to identify levers that would enable a stronger prioritization of the construction of rental dwellings. Moreover, possibilities should be explored for reevaluating the stringency of building and zoning criteria as well as the process for obtaining construction permits, even if challenging for a small and densely populated country like the Netherlands. Such efforts could also contribute to restoring the financial viability of stranded CRE assets as some obsolete office or retail properties may offer the potential for a rededication to other uses if in a desirable location, for instance to alleviate housing bottlenecks. Lastly, climate considerations are bearing on real estate markets, as aptly demonstrated by the decision of Dutch courts to void the government's nitrogen emissions framework in 2019 which had considerable ripple effects on a large number of construction projects. ${ }^{34}$ Indeed, the environmental footprint of structures can bear on their valuations, requiring appropriate incentives to be put in place to modernize the existing building stock as much as feasible to foster its preservation not only from a financial but also from a sustainability perspective. ${ }^{35}$

\footnotetext{
${ }^{34}$ For more details, see Haverkamp et al. (2019).

${ }^{35}$ For an extensive analysis of how energy efficiency can affect the value of real estate, see Zancanella et al. (2018).
} 


\section{References}

AFM (2021): "Financiele Kwetsbaarheid va Huishoudens met een Aflossingsvrije

Hypotheek - Een Analyse op Basis van CBS-microdata", January.

BIS (2019): “Mind the Data Gap: Commercial Property Prices for Policy”, IFC Report No. 8, March.

BIS (2020): "Property Price Dynamics: Domestic and International Drivers", CGFS Paper No. 64, February.

Boumeester, H., and K. Dol (2016): "Eigenwoningbezit en Flexibilisering van de Arbeidsmarkt"،, Real Estate Research Quarterly, 15, March.

CBRE (2021): "Real Estate Market Outlook 2021: The Netherlands - The Uneven Road to Recovery", January.

DNB (2017): “The Housing Market in Major Dutch Cities”, Occasional Studies Vol. 15-1.

DNB (2018): "Risks in the Commercial Real Estate Market", Financial Stability Report, pp. 20-26, October.

DNB (2020a): "Downturn in the Commercial Real Estate Market”, Financial Stability Report, pp. 87-92, June.

DNB (2020b): “A Pandemic Stress Test for the Dutch Banking Sector”, Financial Stability Report, pp. 105-117, June.

DNB (2021a): "The Impact of the Pandemic on the Commercial Real Estate Market", DNB Bulletin, 19 April 2021.

DNB (2021b): "Commercial Real Estate: An Updated Pandemic Stress Test for the Dutch Financial Sector", Financial Stability Report, pp. 17-20, May.

Dustmann, C., Fitzenberger, B., and M. Zimmermann (2018): "Housing Expenditure and Income Inequality" IZA Discussion Paper Series No. 11953, November.

ECB (2011): "Tools for Detecting a Possible Misalignment of Residential Property Prices from Fundamentals", Financial Stability Review, pp. 57-59, June.

ECB (2015): “A Model-Based Valuation Metric for Residential Property Markets”, Financial Stability Review, pp. 45-47, November.

ESRB (2016): "Recommendation of the European Systemic Risk Board of 31 October 2016 on Closing Real Estate Data Gaps (ESRB/2016/14)", Official Journal of the European Union, 31 January 2017.

ESRB (2018): "Report on Vulnerabilities in the EU Commercial Real Estate Sector", November.

ESRB (2019a): "Recommendation of the European Systemic Risk Board of 21 March 2019 Amending Recommendation ESRB/2016/14 on Closing Real Estate Data Gaps (ESRB/2019/3)", Official Journal of the European Union, 13 August 2019. 
ESRB (2019b): "Methodologies for the Assessment of Real Estate Vulnerabilities and Macroprudential Policies: Commercial Real Estate", December.

Ezennia, I. S., and S. O. Hoskara (2019): "Methodological Weaknesses in the Measurement Approaches and Concept of Housing Affordability Used in Housing Research: A Qualitative Study", PLoS ONE 14(8): e0221246, August.

Francke, M. K., and D. W. van Dijk (2021): “Commonalities in Private Commercial Real Estate Market Liquidity and Price Index Returns", Journal of Real Estate Finance and Economics, June.

FSB and IMF (2009): "The Financial Crisis and Information Gaps - Report to the G-20 Finance Ministers and Central Bank Governors", October.

IMF (2020): "Denmark: Financial Sector Assessment Program - Technical Note - Financial Safety Net and Crisis Management Arrangements", August.

IMF (2021a): "Commercial Real Estate - Financial Stability Risks during the COVID-19 Crisis and Beyond”, Global Financial Stability Report, pp. 51-74, April.

IMF (2021b): "Recessions and Recoveries in Labor Markets: Patterns, Policies, and Responses to the COVID-19 Shock", World Economic Outlook, pp. 63-80, April.

IMF (2021c): “Affordable Rental Housing: Making It Part of Europe's Recovery”, Departmental Paper No. 2021/13, May.

Haverkamp, E., Lameijer, J., and A. de Snoo (2019): "Nitrogen, the Environment and Dutch Real Estate",https://www.dlapiper.com/en/us/insights/publications/2019/11/realestate-gazette-36/nitrogen-the-environment-and-dutch-real-estate/.

Johansson, Å., and A. C. Sánchez (2011): “The Price Responsiveness of Housing Supply in OECD Countries”, OECD Economics Department Working Papers No. 837, May.

Kakes, J., Swank, J., and A. F. Tieman (2002): “The Housing Ladder, Taxation, and Borrowing Constraints", DNB WO Research Memoranda No. 688, July.

Keen, M., Klemm, A., and V. Perry (2010): “Tax and the Crisis," Fiscal Studies, Vol. 31, No. 1, pp. 43-79.

Klapwijk, A., Nijskens, R. and E. Buitelaar (2017): "De Omvang van de Vastgoedbeleggingsmarkt in Nederland“, Amsterdam School of Real Estate Research Paper No. 2017-06, August.

Klemm, A., Hebous, S., and C. Waerzeggers (2021): "Capital Income Taxation in the Netherlands", IMF Working Paper No. 21/145, May.

Mehrhoff, J. (2017): “What is 'commercial property'?”, IFC Bulletin No. 46, pp. 193-196, December.

Ministerie van Binnenlandse Zaken en Koninkrijksrelaties (2016): „Wonen in beweging - De resultaten van het WoonOnderzoek Nederland 2015“, April.

MSCI (2019): "MSCI Standards for Real Estate Valuations", June. 
MSCI (2021): "MSCI Property Indexes Methodology”, January.

OECD (2021): “Affordable Housing Database", available at https://www.oecd.org/housing/data/affordable-housing-database/

Zancanella, P., Bertoldi, P. and B. Boza-Kiss: "Energy Efficiency, the Value of Buildings and the Payment Default Risk", JCR Science for Policy Report EUR 29471 EN. 